\title{
Synthesis and pharmacological characterization of $\left[{ }^{125} \mathrm{I}\right]$ MRS1898, a high-affinity, selective radioligand for the rat $\mathbf{A}_{3}$ adenosine receptor
}

\author{
Zhan-Guo Gao • Bao Teng • Haitao Wu • \\ Bhalchandra V. Joshi • Gary L. Griffiths • \\ Kenneth A. Jacobson
}

Received: 14 January 2008 / Accepted: 27 March 2008 / Published online: 5 June 2008

(C) Springer Science + Business Media B.V. 2008

\begin{abstract}
A known selective agonist of the $\mathrm{A}_{3}$ adenosine receptors (AR), MRS1898 [(1'R,2'R, $\left.3^{\prime} \mathrm{S}, 4^{\prime} \mathrm{R}, 5^{\prime} \mathrm{S}\right)-4-\{2-$ chloro-6-[(3-iodophenylmethyl)amino]purin-9-yl\}-1(methylaminocarbonyl)bicyclo[3.1.0]hexane-2,3-diol], was synthesized in radioactive form and characterized pharmacologically. This agonist ligand series, based on nucleoside analogues containing a rigid, bicyclic ring system in place of the ribose moiety, was selected for radiolabeling due to its high $\mathrm{A}_{3} \mathrm{AR}$ affinity across species, with nanomolar binding at both rat and human $\mathrm{A}_{3} \mathrm{ARs}$. The radioiodination of MRS1898 on its $N^{6}-3$-iodobenzyl substituent was accomplished in $76 \%$ radiochemical yield by iododestannylation of a 3-(trimethylstannyl)benzyl precursor. $\left[{ }^{125} \mathrm{I}\right]$ MRS1898 bound to the rat $A_{3} A R$ with a $K_{d}$ value of $0.17 \pm$ $0.04 \mathrm{nM}$ and a $\mathrm{B}_{\max }$ value of $0.66 \pm 0.15 \mathrm{pmol} / \mathrm{mg}$ protein. The competition binding profiles for other agonists and antagonists obtained with this radioligand are similar to those previously obtained with other radioligands. The advantages
\end{abstract}

Z.-G. Gao • B. V. Joshi $・$ K. A. Jacobson $(\bowtie)$

Molecular Recognition Section,

Laboratory of Bioorganic Chemistry,

National Institute of Diabetes and Digestive and Kidney Diseases,

National Institutes of Health,

Bethesda, MD 20892, USA

e-mail: kajacobs@helix.nih.gov

B. Teng $\cdot \mathrm{H}$. Wu $\cdot$ G. L. Griffiths

Imaging Probe Development Center, National Heart, Lung, and Blood Institute, National Institutes of Health,

9800 Medical Center Drive,

Rockville, MD 20850, USA

Present address:

B. V. Joshi

Nektar Therapeutics,

Huntsville, AL 35801, USA of $\left[{ }^{125} \mathrm{I}\right] \mathrm{MRS} 1898$ compared with previously used radioligands are primarily its high selectivity and affinity for the rat $\mathrm{A}_{3} \mathrm{AR}$ and also its facile synthesis and radiochemical stability; however, a relatively high level of nonspecific binding presents a limitation. Thus, we have introduced the first selective radioligand for the rat $\mathrm{A}_{3} \mathrm{AR}$.

Keywords Iodination $\cdot G$ protein-coupled receptor . Binding assay $\cdot$ Purine $\cdot$ Nucleoside $\cdot$ Carbocyclic
Abbreviations
AR
adenosine receptor
$\mathrm{CHO}$
Chinese hamster ovary
IB-MECA
$N^{6}$-(3-iodobenzyl)-5'-N-
I-AB-MECA
methylcarboxamidoadenosine
MRS1191
$N^{6}$-(4-amino-3-iodobenzyl)-5'- $N$ -
methylcarboxamidoadenosine
1,4-dihydro-2-methyl-6-phenyl-4-
(phenylethynyl)-3,5-pyridinedicarboxylic acid, 3-ethyl- 5-(phenylmethyl) ester
MRS1220
$N$-[9-chloro-2-(2-furanyl)[1,2,4] triazolo
MRS1523
[1,5-c]quinazolin-5-yl]benzeneacetamide
5-propyl-2-ethyl-4-propyl-3-(ethylsulfa-
nylcarbonyl)-6-phenylpyridine-
5-carboxylate
MRS1898 MRS1898, (1'R,2'R,3'S,4'R,5'S)-4-\{2-
chloro-6-[(3-iodophenylmethyl)amino]
purin-9-yl -1-(methylaminocarbonyl)
bicyclo[3.1.0]hexane-2,3-diol
NECA 5'- $N$-ethylcarboxamidoadenosine
Cl-IB-MECA 2-chloro- $N^{6}$-(3-iodobenzyl)-5'-
$N$-methylcarboxamidoadenosine
MRE 3008F20 5-[[(4-methoxyphenyl)amino]carbonyl] amino-8-propyl-2-(2-furyl)-pyrazolo [4,3-e]1,2,4-triazolo[1,5-c]pyrimidine 
PSB-11 (R)-4-methyl-8-ethyl-2-phenyl-imidazo $[2,1-i]$ purin-5-one

HEMADO 2-hexyn-1-yl- $N^{6}$-methyladenosine

\section{Introduction}

Adenosine regulates many physiological functions through specific cell membrane receptors. The $\mathrm{A}_{3}$ adenosine receptor $\left(A_{3} A R\right)$ plays an important role in brain ischemia, immunosuppression, and bronchospasm in several animal models [1]. $\mathrm{A}_{3} \mathrm{AR}$ agonists, such as Cl-IB-MECA (2, Chart 1), are currently in clinical trials for various metastatic and inflammatory conditions [2-5]. The $\mathrm{A}_{3} \mathrm{AR}$ is elevated in tumors, and its expression level correlates to tumor responsiveness to therapy, such as the $\mathrm{A}_{3} \mathrm{AR}$ agonist $N^{6}$-(3-iodobenzyl)-5'- $N$-methylcarboxamidoadenosine (IBMECA 1) [6, 7].

A number of radioligands have been used for the study of the $A_{3} A R$ [8-12]. Radioligands for the $A_{3} A R$ may be promising diagnostic markers for cancer and possibly other diseases, whereas characterization and quantification of the $\mathrm{A}_{3} \mathrm{AR}$ in vivo in patients may also be a useful tool in both research and therapeutic studies [13]. The nucleoside $N^{6}$-(4amino-3-iodobenzyl)-5'-N-methylcarboxamidoadenosine
([ $\left.\left.{ }^{125} \mathrm{I}\right] \mathrm{I}-\mathrm{AB}-\mathrm{MECA} 3\right)\left(\mathrm{K}_{\mathrm{d}} \sim 1 \mathrm{nM}\right.$ at human $(\mathrm{h})$ and rat $(\mathrm{r})$ $\mathrm{A}_{3} \mathrm{AR}$ ) was introduced in 1994 as a radioligand for $\mathrm{A}_{3} \mathrm{AR}$ and is the most commonly used radioligand for in vitro studies of that subtype [8]. Several other agonist radioligands have been used in previous studies. All of the $\mathrm{A}_{3} \mathrm{AR}$ radioligands so far in use show major deficiencies. For example, the antagonist heterocyclic radioligands, $\left[{ }^{3} \mathrm{H}\right]$ MRE 3008F20 4 and $\left[{ }^{3} \mathrm{H}\right] \mathrm{PSB}-11$ 5, have been used for the study of the $\mathrm{hA}_{3} \mathrm{AR}$; however, they do not bind effectively to the $\mathrm{rA}_{3} \mathrm{AR}$ or mouse $\mathrm{A}_{3} \mathrm{AR}[9,10] . \mathrm{A}_{3} \mathrm{AR}$ agonists are often more consistent than nonnucleoside antagonists in their high affinity at that subtype, independent of species. Nevertheless, most of the agonist radioligands for characterizing the $\mathrm{A}_{3} \mathrm{AR}$ are not truly $\mathrm{A}_{3} \mathrm{AR}$ selective. Although the agonist $N^{6}$-(4-amino-3-iodophenylethyl)-adenosine $\left(\left[{ }^{125} \mathrm{I}\right] \mathrm{I}-\mathrm{APNEA}\right)$ showed reasonable affinity for the $\mathrm{rA}_{3} \mathrm{AR}$ $\left(\mathrm{K}_{\mathrm{d}}=15 \mathrm{nM}\right)$, it is even more potent for the $\mathrm{rA}_{1} \mathrm{AR}\left(\mathrm{K}_{\mathrm{d}}=\right.$ $1.32 \mathrm{nM})[8,21]$; $\left[{ }^{125} \mathrm{I}\right] \mathrm{I}-\mathrm{AB}-\mathrm{MECA} \mathbf{3}$ has a similar affinity for $\mathrm{rA}_{1}$ and $\mathrm{rA}_{3} \mathrm{ARs}\left(\mathrm{A}_{3}=1.48 \mathrm{nM} ; \mathrm{A}_{1}=3.42 \mathrm{nM}\right) .5^{\prime}-\mathrm{N}$ ethylcarboxamidoadenosine $\left(\left[{ }^{3} \mathrm{H}\right] \mathrm{NECA}\right)$, showed a reasonable binding affinity at the $\mathrm{hA}_{3} \mathrm{AR}\left(\mathrm{K}_{\mathrm{d}}=6 \mathrm{nM}\right)$ but is nonselective and weak at the $\mathrm{rA}_{3} \mathrm{AR}$ [11]. Recently, a new $\mathrm{A}_{3} \mathrm{AR}$ agonist radioligand, $\left[{ }^{3} \mathrm{H}\right] \mathrm{HEMADO} \mathbf{6}$, which contains an $N^{6}$-methyl group, showed high affinity $\left(\mathrm{K}_{\mathrm{d}}=\right.$ $1.1 \mathrm{nM}$ at the $\mathrm{hA}_{3} \mathrm{AR}$ ), selectivity, and low nonspecific

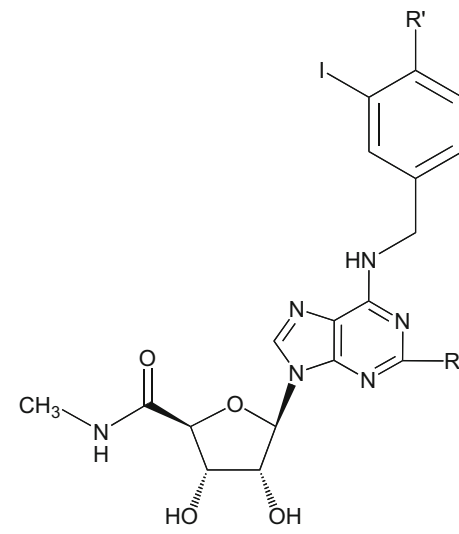

$1 \mathrm{R}=\mathrm{H}, \mathrm{R}^{\prime}=\mathrm{H}$ IB-MECA $2 \mathrm{R}=\mathrm{Cl}, \mathrm{R}^{\prime}=\mathrm{H} \quad \mathrm{Cl}-\mathrm{IB}-\mathrm{MECA}$ $3 \mathrm{R}=\mathrm{H}, \mathrm{R}^{\prime}=\mathrm{NH}_{2}$ I-AB-MECA

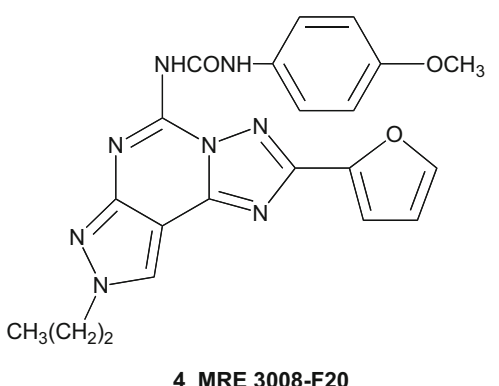

4 MRE 3008-F20<smiles>CCC1CN2C(=O)N(C)c3nc(-c4ccccc4)[nH]c3C2=N1</smiles>

5 PSB-11

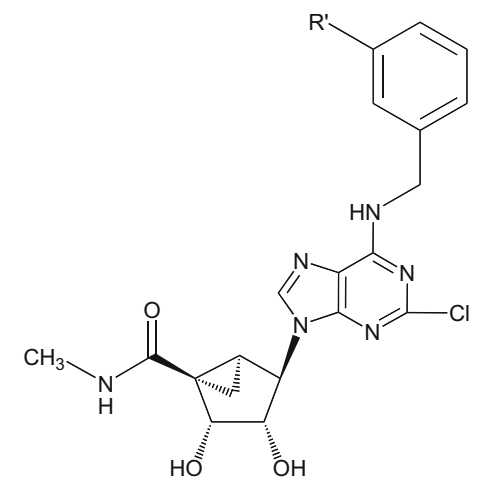

$7 \mathrm{R}^{\prime}=1 \quad$ MRS1898

$8 \mathrm{R}^{\prime}=\mathrm{Br}$ MRS3581

6 HEMADO

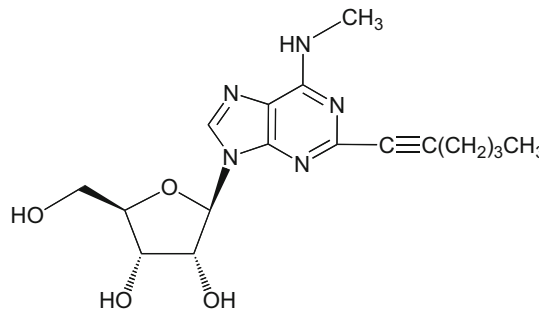

Chart 1 Structures of nucleoside and nonnucleoside, high-affinity ligands for the $\mathrm{A}_{3}$ adenosine receptor. Compounds 3-6 were previously prepared in radioactive form for use in receptor labeling and characterization 
binding. However, it has no effect on the $\mathrm{rA}_{3} \mathrm{AR}$ [12], which is consistent with previous findings that $N^{6}$-methylsubstituted adenosine derivatives are potent at the $\mathrm{hA}_{3} \mathrm{AR}$ but not $\mathrm{rA}_{3} \mathrm{AR}[14,15]$. For example, the parent nucleoside $N^{6}$-methyladenosine has $\mathrm{K}_{\mathrm{i}}$ values of $6390 \mathrm{nM}$ at the $\mathrm{rA}_{3} \mathrm{AR}$ and $9.3 \mathrm{nM}$ at the $\mathrm{hA}_{3} \mathrm{AR}$.

Thus, the challenge remains to develop a subtypeselective radioligand for the $\mathrm{A}_{3} \mathrm{AR}$ in rat and other nonprimate species. A new nucleoside derivative, $\left(1^{\prime} \mathrm{R}, 2^{\prime} \mathrm{R}, 3^{\prime}\right.$ $\left.\mathrm{S}, 4^{\prime} \mathrm{R}, 5^{\prime} \mathrm{S}\right)-4-\{2$-chloro-6-[(3-iodophenylmethyl)amino] purin-9-yl $\}-1$-(methylaminocarbonyl)bicyclo[3.1.0]hexane2,3-diol) (MRS1898 7), containing the (N)-methanocarba (bicyclo[3.1.0]hexane) ring system as a ribose substitute, displays high potency and selectivity for the $h A_{3} A R$ compared with other $\mathrm{A}_{3} \mathrm{AR}$ agonists, such as IB-MECA 1 [16-18]. This bicyclic ring system maintains a conformation that is preferred at the $\mathrm{A}_{3} \mathrm{AR}$ and thus tends to increase selectivity for the $\mathrm{hA}_{3} \mathrm{AR}$. MRS1898 7 has previously been shown to bind with high affinity at the $\mathrm{rA}_{3} \mathrm{AR}$. Its affinity profile at three $A R$ subtypes is as follows: $\mathrm{rA}_{1}=83.9 \pm$ $10.3 \mathrm{nM}, \mathrm{hA}_{1}=136 \pm 22 \mathrm{nM} ; \mathrm{rA}_{2 \mathrm{~A}}=1660 \pm 260 \mathrm{nM}, \mathrm{hA}_{2 \mathrm{~A}}=$ $784 \pm 97 \mathrm{nM} ; \mathrm{rA}_{3}=1.1 \pm 0.1 \mathrm{nM}, \mathrm{hA}_{3}=1.51 \pm 0.23 \mathrm{nM}$. In this study, we synthesized a radioiodinated form of this adenosine derivative for preliminary in vitro studies and characterized its binding properties at the $\mathrm{rA}_{3} \mathrm{AR}$.

\section{Materials and methods}

General All chemical synthetic reagents and pharmacological agents were purchased from Sigma-Aldrich Chemical Company, except where noted. Sodium $\left[{ }^{125} \mathrm{I}\right]$ iodide $(17.4 \mathrm{Ci} / \mathrm{mg})$ in sodium hydroxide $(\mathrm{NaOH})\left(1.0 \times 10^{-5} \mathrm{M}\right)$ was supplied by Perkin-Elmer Life and Analytical Science. Iodogen iodination reagent was purchased from Pierce Biotechnology. High-performance liquid chromatography
(HPLC) was performed using an Agilent 1200 Series LCMS system or a Beckman Gold HPLC system equipped with a Model 126 programmable solvent module, a Model 168 variable wavelength detector, a $\beta$-Ram Model 4 radioisotope detector, and Beckman System Gold remote interface module SS420X, using $32 \mathrm{Karat}^{\circledR}$ software. These analyses were performed on Agilent Eclipse XDB-C18 $(3.5 \mu \mathrm{m}, 3.0 \times 75 \mathrm{~mm})$ and XDB-C18 $(5 \mu \mathrm{m}, 4.6 \times$ $250 \mathrm{~mm}$ ) columns.

\section{Preparation of [ $\left.{ }^{125} I\right] M R S 1898\left[\left(1^{\prime} R, 2^{\prime} R, 3^{\prime} \Sigma, 4^{\prime} R, 5^{\prime} \Sigma\right)-4-\right.$ \{2-chloro-6-[(3-iodophenylmethyl)amino]purin-9-yl\}-1- (methylaminocarbonyl)bicyclo[3.1.0] hexane-2,3-diol] (10)}

MRS1898 (0.018 g, $0.033 \mathrm{mmol}), \mathrm{PdCl}_{2}\left(\mathrm{PPh}_{3}\right)_{2}(5 \mathrm{mg})$, and hexamethyltin $(0.032 \mathrm{~g}, 0.1 \mathrm{mmol})$ were mixed together in anhydrous dioxane $(3 \mathrm{ml})$, and the resulting reaction mixture was stirred at $70{ }^{\circ} \mathrm{C}$ for $2 \mathrm{~h}$. The mixture was concentrated under reduced pressure. The product was purified by preparative thin layer chromatography by using chloroform $\left(\mathrm{CHCl}_{3}\right)$ : $\mathrm{MeOH}$ as the eluant to afford the stannyl derivative $1(0.008 \mathrm{~g}, 45 \%)$ as an oil. Highresolution mass spectrometry (HRMS) $(\mathrm{M}+1)^{+}$: calculated 593.1090, found 593.1099. HPLC: $R_{\mathrm{t}}=21.95$ min. HPLC system: $5 \mathrm{mM}$ TBAP $/ \mathrm{CH}_{3} \mathrm{CN}$ from $80 / 20$ to $60 / 40$ in $25 \mathrm{~min}$, then isocratic for $2 \mathrm{~min}$; flow rate of $1 \mathrm{ml} / \mathrm{min}$.

Regeneration of MRS1898 The trimethylstannyl intermediate $10(0.1 \mathrm{mg})$ was reconverted to MRS1898 upon dissolving in $\mathrm{MeOH}(0.1 \mathrm{ml})$ followed by treatment with $\mathrm{I}_{2}$ $(0.1 \mathrm{M}$ in $\mathrm{MeOH}, 0.1 \mathrm{ml})$ for $10 \mathrm{~min}$ at room temperature (Scheme 1). The structure was confirmed by HPLC and HRMS. HRMS $(\mathrm{M}+1)^{+}$: calculated 555.0408, found 555.0408. HPLC: $R_{\mathrm{t}}=15.91 \mathrm{~min}$ (same system as above).
Scheme 1 Synthesis of a stannyl precursor 10 and the iodination (reverse) reaction used in nonradioactive generation of $\left[\left(1^{\prime} \mathrm{R}, 2^{\prime} \mathrm{R}, 3^{\prime} \Sigma, 4^{\prime} \mathrm{R}\right.\right.$, $\left.5^{\prime} \Sigma\right)$-4-\{2-chloro-6-[(3-iodophenylmethyl)amino]purin-9-yl\}-1(methylaminocarbonyl)bicyclo [3.1.0]hexane-2,3-diol] (MRS1898)

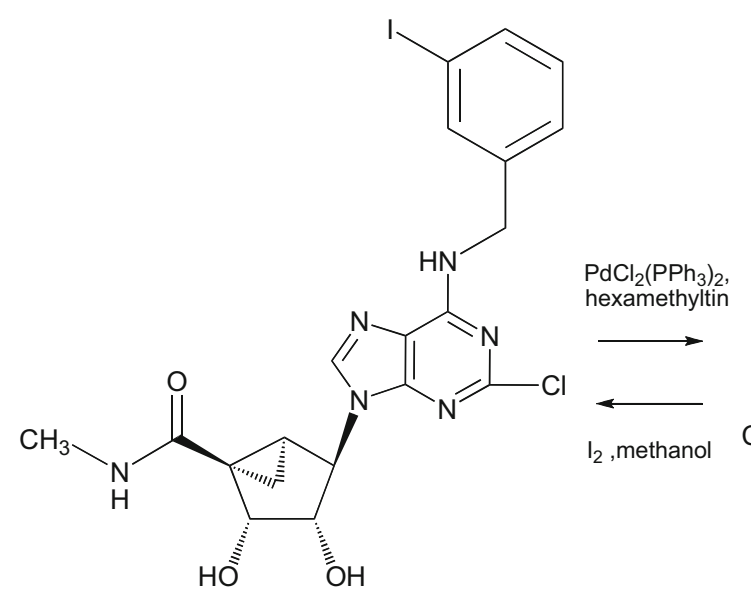

7, MRS1898

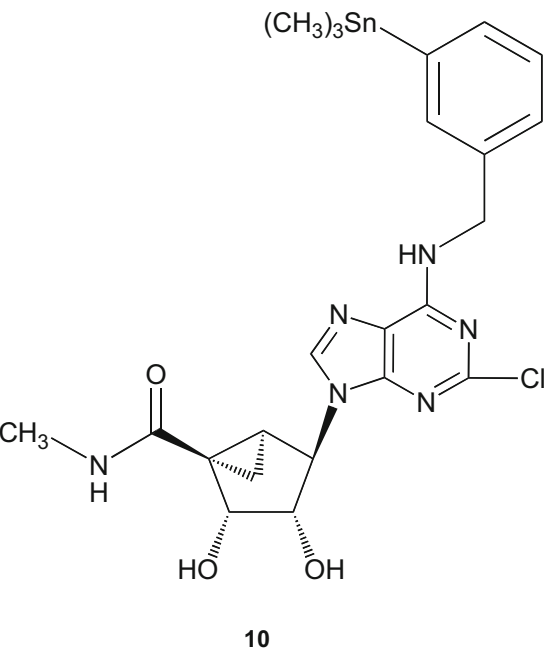


In a separate experiment that was more predictive of the subsequent radioiodination conditions, the trimethylstannyl precursor $10(0.2 \mathrm{mg}, 0.34 \mu \mathrm{mol})$ was dissolved in $50 \mathrm{ul}$ of methanol in an Eppendorf vial, and to this solution was added an iodine-methanol solution (100 ul of $8 \mathrm{mg} / \mathrm{ml})$. The vial contents were shaken for $30 \mathrm{~min}$ and the crude product analyzed on an Agilent 1200 Series LiquidChromatography Mass Spectrometry (LC-MS). MRS1898 eluted at $7.6 \mathrm{~min}$ with a molecular weight of 555.1 that showed $[\mathrm{M}+\mathrm{H}]^{+}$.

Radiolabeling of MRS1898: method 1 The radioiodination of MRS1898 was performed using tert-butyl hydroperoxide (TBHP) as an oxidant (Scheme 2) [19]. Next, 15 ul of TBHP (10\% solution in chloroform) was added into a vvial. To this solution were added an acetic acid solution (4 ul, 3\% in chloroform) and a sodium $\left[{ }^{125} \mathrm{I}\right]$ iodide solution (4 ul, $14.8 \mathrm{MBq}, 3.7 \mathrm{GBq} / \mathrm{ml}$ ), followed by the trimethylstannyl precursor 10 (50 ul, $0.2 \mathrm{mg}$ in chloroform). The reaction mixture was mixed under vortex for $30 \mathrm{~min}$ at room temperature. The final labeled product was separated using a Beckman System Gold HPLC equipped with an Agilent Eclipse XDB-C18 column $(5.0 \mu \mathrm{m}, 4.6 \times 250 \mathrm{~mm})$ under the following conditions: solvent $\mathrm{A}$ was $0.1 \%$ trifluoroacetic acid (TFA) in water; solvent B was $0.1 \%$ TFA in acetonitrile. A linear gradient of solvent B from $20 \%$ to $50 \%$ over $25 \mathrm{~min}$ was used at a flow rate of $1 \mathrm{ml} / \mathrm{min}$; $\left[{ }^{125} \mathrm{I}\right] \mathrm{MRS} 1898$ eluted at $23 \mathrm{~min}$. The fraction containing $\left[{ }^{125} \mathrm{I}\right] \mathrm{MRS} 1898$ was concentrated and loaded onto an Agilent Eclipse XDB-C18 column $(3.5 \mu \mathrm{m}, 3.0 \times 75 \mu \mathrm{mm})$. The mobile phase was the same as above, and a linear gradient of solvent B from $20 \%$ to $45 \%$ over 12 min was used at a flow rate of $1 \mathrm{ml} / \mathrm{min}$; [ $\left.{ }^{125} \mathrm{I}\right] \mathrm{MRS} 1898$ eluted at $9.0 \mathrm{~min}$. The radiochemical purity was $>98 \%$, the specific activity was $3.94 \mathrm{Ci} / \mathrm{mg}$, and the radiochemical yields were $75.6 \%$.

Radiolabeling of MRS1898: method 2 The second radioiodination of the trimethylstannyl MRS1898 10 with $\mathrm{Na}$ $\left[{ }^{125} \mathrm{I}\right]$ iodide was accomplished using iodogen as an oxidant (Scheme 2). Iodogen solution (60 ul, $0.33 \mathrm{mg} / \mathrm{ml}$ in chloroform) and sodium $\left[{ }^{125} \mathrm{I}\right]$ iodide solution (3 ul, 11.1 MBq, 3.7 GBq/ml) were transferred into a v-vial. To this solution was added the trimethylstannyl precursor 10 (50 ul, $0.2 \mathrm{mg}$ in chloroform). The reaction mixture was mixed under vortex for $30 \mathrm{~min}$ at room temperature, and the $\left[{ }^{125} \mathrm{I}\right] \mathrm{MRS} 1898$ was purified using the same conditions as used in method 1 . The radiochemical purity was $>98 \%$, the specific activity was $3.94 \mathrm{Ci} / \mathrm{mg}$, and the radiochemical yield was $54.5 \%$. The $\left[{ }^{125} \mathrm{I}\right] \mathrm{MRS} 1898$ was stored in solution (ethanol: water $=9: 1, \mathrm{v} / \mathrm{v}$ ) containing $1 \%$ ascorbic acid for inhibition of radiolytic processes.

\section{Pharmacology}

The binding experiments were done as previously described $[8,14]$ on Chinese hamster ovary $(\mathrm{CHO})$ cell membranes expressing the recombinant $\mathrm{rA}_{3} \mathrm{AR}$ and on membranes from rat-brain cortex, mainly expressing the $\mathrm{A}_{1} \mathrm{AR}$; and rat striatum, expressing the $\mathrm{A}_{2 \mathrm{~A}} \mathrm{AR}$ endogenously. In brief, the saturation, displacement and kinetic experiments were performed using membrane preparations from $\mathrm{CHO}$ cells expressing $\mathrm{rA}_{3} \mathrm{AR}$ in a total assay volume of $100 \mu \mathrm{l}$, including $25 \mu \mathrm{l}$ of radioligand, $50 \mu \mathrm{l}$ membranes, and $25 \mu \mathrm{l}$ of test compounds or other ingredients. Nonspecific binding was determined in the presence of $10 \mu \mathrm{M}$ IB-MECA. The mixtures were incubated at $25^{\circ} \mathrm{C}$ for $60 \mathrm{~min}$, followed by filtration with a 24-well Brandell MT-24 harvester. Radioactivity was determined in a Beckman 5500B $\gamma$-counter. For the dissociation experiment, the mixture was first incubated for $60 \mathrm{~min}, 10 \mu \mathrm{M}$ IB-MECA was added, and reaction was terminated at various time points, as indicated. Binding parameters were calculated using Prism 4.0 software (GraphPAD, San Diego, CA, USA). IC 50 values obtained from competition curves were converted to $\mathrm{K}_{\mathrm{i}}$ values using the Cheng-Prusoff equation [20]. Data are
Scheme 2 Radiosynthesis of $\left[\left(1^{\prime} \mathrm{R}, 2^{\prime} \mathrm{R}, 3^{\prime} \Sigma, 4^{\prime} \mathrm{R}, 5^{\prime} \Sigma\right)-4-\{2-\right.$ chloro-6-[(3-iodophenylmethyl) amino]purin-9-yl $\}$-1-(methylaminocarbonyl)bicyclo[3.1.0] hexane-2,3-diol] ([ $\left.{ }^{125} \mathrm{I}\right]$ MRS1898)

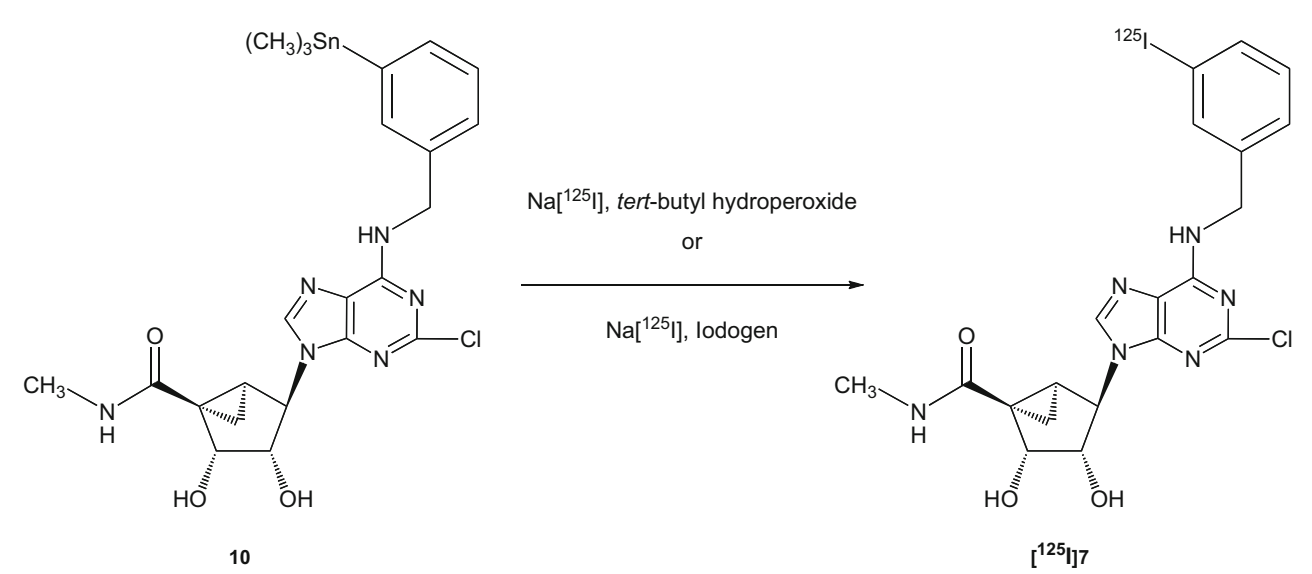


expressed as mean \pm standard error. cLogP values were calculated using ChemDraw Ultra (Version 11.0).

\section{Results \\ Chemistry}

It was hoped that a new radioligand would permit better analysis of tissue distribution of the $\mathrm{A}_{3} \mathrm{AR}$. As MRS1898 already contains an iodine atom that is associated with high receptor affinity, that position was selected for convenient radiolabeling. A common method for rapidly introducing radioactive iodine on an aromatic ring is to use a stannyl precursor. The feasibility of this route was demonstrated through a "cold" iodination reaction (Scheme 1). The trimethylstannyl precursor 10 was generated in one step from MRS1898 using a palladium reagent and hexamethyltin. Protection of the hydroxyl groups or the exocyclic amine of this adenosine analogue was not necessary. Compound 10 was stable upon storage at $-8^{\circ} \mathrm{C}$ for several months. This intermediate 10 rapidly reverted to MRS 1898 upon treatment with iodine. The radioiodination of MRS1898 was accomplished through a similar iododestannylation of 10 using sources of ${ }^{125} \mathrm{I}$ and by two different radioiodination methods (Scheme 2). The tertiary-butyl hydroperoxide (TBHP) method [19] provided a superior yield in comparison with iodogen. The stability of $\left[{ }^{125} \mathrm{I}\right]$ MRS1898 solution (ethanol:water $=9: 1, \mathrm{v} / \mathrm{v}$ ) containing $1 \%$ ascorbic acid over 1 month when stored at $-20^{\circ} \mathrm{C}$ was reliable, as reported in Table 1.

\section{Pharmacology}

The new radioligand was examined in standard radioreceptor binding experiments. The $\mathrm{rA}_{3} \mathrm{AR}$ was expressed heterologously in $\mathrm{CHO}$ cells [21], from which membranes were prepared for binding experiments. Initially, the nonspecific binding of $\left[{ }^{125} \mathrm{I}\right] \mathrm{MRS} 1898$ to $\mathrm{CHO}$ cell membranes expressing the $\mathrm{rA}_{3} \mathrm{AR}$ was extremely high,

Table 1 The radiochemical purities of a $\left(1^{\prime} \mathrm{R}, 2^{\prime} \mathrm{R}, 3^{\prime} \mathrm{S}, 4^{\prime} \mathrm{R}, 5^{\prime} \mathrm{S}\right)-4-\{2-$ chloro-6-[(3-iodophenylmethyl)amino]purin-9-yl\}-1-(methylaminocarbonyl)bicyclo[3.1.0]hexane-2,3-diol ([ $\left.\left.{ }^{125} \mathrm{I}\right] \mathrm{MRS} 1898\right)$ solution at various time points ${ }^{\mathrm{a}}$

\begin{tabular}{lllllll}
\hline Time (days) & 2 & 8 & 11 & 20 & 25 & 27 \\
\hline Radiochemical purity & $98 \%$ & $98.5 \%$ & $98.5 \%$ & $100 \%$ & $100 \%$ & $100 \%$
\end{tabular}

${ }^{a}$ Determined by high-performance liquid chromatography (HPLC) with radioactivity detection. [ $\left.{ }^{125} \mathrm{I}\right] \mathrm{MRS} 1898$ was present at a concentration of $6.9 \mathrm{nM}$ in solution (ethanol:water $=9: 1, \mathrm{v} / \mathrm{v}$ ) containing $1 \%$ ascorbic acid and stored at $-20^{\circ} \mathrm{C}$.

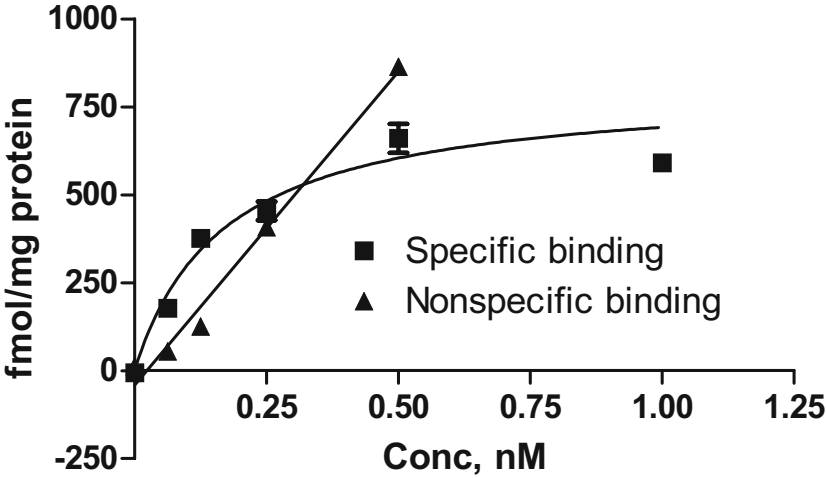

Fig. 1 Saturation of binding of $\left(1^{\prime} \mathrm{R}, 2^{\prime} \mathrm{R}, 3^{\prime} \mathrm{S}, 4^{\prime} \mathrm{R}, 5^{\prime} \mathrm{S}\right)-4-\{2$-chloro-6[(3-iodophenylmethyl)amino]purin-9-yl\}-1-(methylaminocarbonyl) bicyclo[3.1.0]hexane-2,3-diol ([ $\left.\left.{ }^{125} \mathrm{I}\right] \mathrm{MRS} 1898\right)$ at the rat $\mathrm{A}_{3}$ adenosiner receptor (AR). Experiments were performed using membrane preparations $(20 \mu \mathrm{g}$ protein) from Chinese hamster ovary $(\mathrm{CHO})$ cells expressing rat $\mathrm{A}_{3} \mathrm{AR}$ in a total assay volume of $100 \mu \mathrm{l}$, including $25 \mu \mathrm{l}$ of radioligand, $50 \mu \mathrm{l}$ membranes, and $25 \mu \mathrm{l}$ buffer (total binding) or $25 \mu \mathrm{l}$ of $10 \mu \mathrm{M} N^{6}$-(3-iodobenzyl)-5'-N-methylcarboxamidoadenosine (IB-MECA) (nonspecific binding). The mixtures were incubated at $25^{\circ} \mathrm{C}$ for $60 \mathrm{~min}$, followed by filtration with a 24-well harvester

almost inseparable from its total binding. After soaking the glass fiber filters with polyethyleneimine $(0.1 \%)$, the ratio of specific to nonspecific binding (at a concentration of $0.1 \mathrm{nM}$ radioligand) was improved (3-4:1) and acceptable

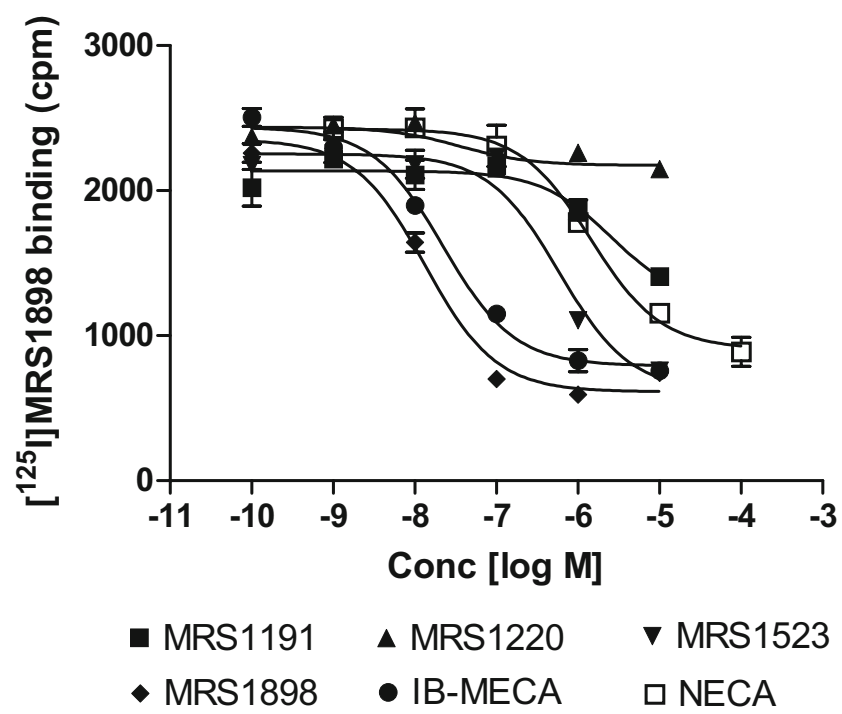

Fig. 2 Competition for binding of (1'R, $\left.2^{\prime} \mathrm{R}, 3^{\prime} \mathrm{S}, 4^{\prime} \mathrm{R}, 5^{\prime} \mathrm{S}\right)-4$ - $\{2$-chloro-6[(3-iodophenylmethyl)amino]purin-9-yl $\}$-1-(methylaminocarbonyl)bicyclo[3.1.0]hexane-2,3-diol ([ $\left.\left.{ }^{125} \mathrm{I}\right] \mathrm{MRS1898}\right)(0.1 \mathrm{nM})$ at the rat $\mathrm{A}_{3}$ adenosine receptor (AR) by $\mathrm{A}_{3} \mathrm{AR}$ agonists and antagonists. The $\mathrm{y}-$ axis shows radioactivity counts corresponding to total binding. The $\mathrm{K}_{\mathrm{i}}$ values ( $\mathrm{nM} \pm$ standard error of the mean) were: 1,4-dihydro-2-methyl-6phenyl-4-(phenylethynyl)-3,5-pyridinedicarboxylic acid, 3-ethyl- 5(phenylmethyl) ester (MRS1191) (1,850 \pm 386$), N$-[9-chloro-2-(2-furanyl) $[1,2,4]$ triazolo[1,5-c]quinazolin-5-yl]benzeneacetamide (MRS1220) (>10,000), 5-propyl-2-ethyl-4-propyl-3-(ethylsulfanylcarbonyl)-6-phenylpyridine-5-carboxylate (MRS1523) (518 \pm 236$)$, MRS1898 (7.8 \pm 2.5$), N^{6}$ -

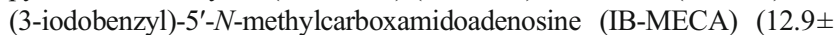
$3.7)$ and 5 - $N$-ethylcarboxamidoadenosine (NECA) $(872 \pm 251)$ 
for drug screening, although the ratio was still low when the radioligand concentration was raised.

The specific binding of $\left[{ }^{125} \mathrm{I}\right] \mathrm{MRS} 1898$ to the $\mathrm{rA}_{3} \mathrm{AR}$ in $\mathrm{CHO}$ cell membranes was saturable (Fig. 1), and Scatchard analysis indicated a $K_{d}$ value of $0.17 \pm 0.04 \mathrm{nM}$ and a $B_{\max }$ value of $0.66 \pm 0.15 \mathrm{pmol} / \mathrm{mg}$ protein.

The ability of various known AR agonists and antagonists to compete for $\left[{ }^{125} \mathrm{I}\right] \mathrm{MRS} 1898$ binding to the $\mathrm{rA}_{3} \mathrm{AR}$ was tested. Figure 2 shows that the rank order of potencies for agonists was MRS1898 $\geq$ IB-MECA $>$ NECA, and for antagonists 5-propyl-2-ethyl-4-propyl-3-(ethylsulfanylcarbonyl)-6-phenylpyridine-5-carboxylate (MRS1523) > 1,4-dihydro-2-methyl-6-phenyl-4-(phenylethynyl)-3,5-pyridinedicarboxylic acid, 3-ethyl- 5-(phenylmethyl) ester (MRS1191) > N-[9-chloro-2-(2-furanyl)[1,2,4]triazolo[1,5c]quinazolin-5-yl]benzeneacetamide (MRS1220), which is similar to those obtained with other radioligands in previous reports.

In the association kinetic experiment (Fig. 3A), $\left[{ }^{125} \mathrm{I}\right]$ MRS1898 binding reached a maximum in $30 \mathrm{~min}$, with a $\mathrm{t}_{1 / 2}$ of $7.4 \pm 0.9 \mathrm{~min}$. After a $60 \mathrm{~min}$ incubation, the dissociation was initiated with the addition of $10 \mu \mathrm{M}$ IB-MECA at various time points, as indicated in Fig. $3 \mathrm{~b}$.
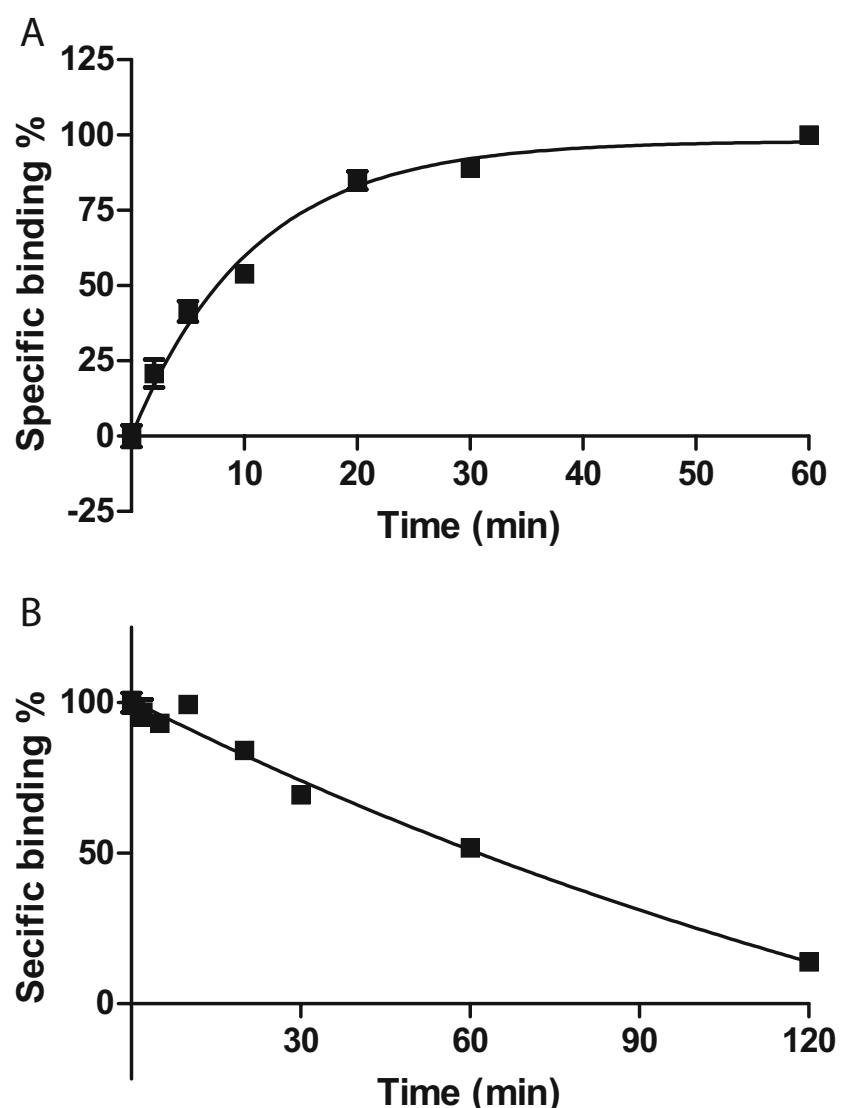

Fig. 3 Kinetics of association (a) and dissociation (b) of $\left(1^{\prime} \mathrm{R}, 2^{\prime} \mathrm{R}, 3^{\prime}\right.$ $\left.\mathrm{S}, 4^{\prime} \mathrm{R}, 5^{\prime} \mathrm{S}\right)-4-\{2$-chloro-6-[(3-iodophenylmethyl)amino]purin-9-yl\}-1(methylaminocarbonyl)bicyclo[3.1.0]hexane-2,3-diol ([ $\left.{ }^{125} \mathrm{I}\right]$ MRS1898) $(0.1 \mathrm{nM})$ at the rat $\mathrm{A}_{3}$ adenosine receptor

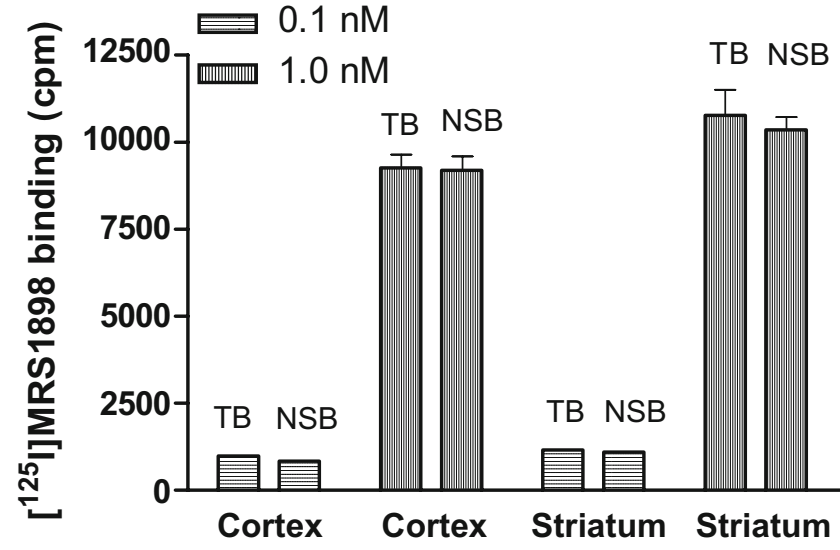

Fig. 4 Binding of $\left(1^{\prime} \mathrm{R}, 2^{\prime} \mathrm{R}, 3^{\prime} \mathrm{S}, 4^{\prime} \mathrm{R}, 5^{\prime} \mathrm{S}\right)-4-\{2$-chloro-6-[(3-iodophenylmethyl)amino]purin-9-yl $\}-1$-(methylaminocarbonyl)bicyclo[3.1.0] hexane-2,3-diol ([ $\left.\left.{ }^{125} \mathrm{I}\right] \mathrm{MRS} 1898\right)$ in membranes from rat-brain cortex [mainly $\mathrm{A}_{1}$ adenosine receptor (AR)] and striatum (expressing both $\mathrm{A}_{1} \mathrm{AR}$ and $\mathrm{A}_{2 \mathrm{~A}} \mathrm{AR}$ ). Two concentrations of $\left[{ }^{125} \mathrm{I}\right] \mathrm{MRS} 1898$ (0.1 and $1.0 \mathrm{nM})$ were used. The membrane concentration used in the experiment was $200 \mu \mathrm{g} / \mathrm{mg}$ protein). The $y$-axis shows radioactivity counts. The first bar (TB, total binding) in each pair of bars corresponds to total radioligand binding, and the second bar (NSB, nonspecific binding) is in the presence of $10 \mu \mathrm{M} \mathrm{N} N^{6}$-cyclopentyladenosine for $\mathrm{A}_{1} \mathrm{AR}$ and $10 \mu \mathrm{M}$ 2-[p-(2-carboxyethyl)phenyl-ethylamino]-5'- $N$-ethylcarboxamidoadenosine for $\mathrm{A}_{2 \mathrm{~A}} \mathrm{AR}$. Thus, no specific binding of $\left[{ }^{125} \mathrm{I}\right] \mathrm{MRS} 1898$ to the $\mathrm{A}_{1} \mathrm{AR}$ and $\mathrm{A}_{2 \mathrm{~A}} \mathrm{AR}$ in rat brain was detected

The binding of $\left[{ }^{125} \mathrm{I}\right] \mathrm{MRS} 1898$ was further tested using membranes prepared from rat-brain cortex (mainly $A_{1} A R$ ) and striatum (expressing both $\mathrm{A}_{1} \mathrm{AR}$ and $\mathrm{A}_{2 \mathrm{~A}} \mathrm{AR}$ ). It was found that no specific binding to either the $\mathrm{rA}_{1} \mathrm{AR}$ or $\mathrm{rA}_{2 \mathrm{~A}} \mathrm{AR}$ could be demonstrated (Fig. 4) at both low $(0.1 \mathrm{nM})$ and high $(1.0 \mathrm{nM})$ concentrations of $\left[{ }^{125} \mathrm{I}\right]$ MRS1898 using a membrane concentration as high as $200 \mu \mathrm{g} / \mathrm{mg}$ protein.

\section{Discussion}

In this study, we synthesized and pharmacologically characterized the new radioligand $\left[{ }^{125} \mathrm{I}\right] \mathrm{MRS} 1898$ for the $\mathrm{rA}_{3} \mathrm{AR}$. The agonist ligand series of which MRS1898 is representative, based on nucleoside analogues containing a rigid, bicyclic ring system in place of the ribose moiety, was selected for radiolabeling due to its high $\mathrm{A}_{3} \mathrm{AR}$ affinity across species. The radioiodination of MRS1898 on its $N^{6}-3$-iodobenzyl substituent was accomplished in $76 \%$ radiochemical yield by iododestannylation of a 3-(trimethylstannyl)benzyl precursor 10. This precursor was both synthesized and iodinated without protecting groups present at other sensitive positions of the nucleoside.

As a receptor radioligand, $\left[{ }^{125} \mathrm{I}\right] \mathrm{MRS} 1898$ may be useful for compound screening, testing of ligand binding affinity, and for studying association and dissociation kinetics at the $\mathrm{rA}_{3} \mathrm{AR}$. Although $\left[{ }^{125} \mathrm{I}\right] \mathrm{MRS} 1898$ could be potentially 
useful for the study of the $\mathrm{rA}_{3} \mathrm{AR}$, there are also some potential problems with this radioligand, particularly its high nonspecific binding under the conditions used in this study. The $\mathrm{K}_{\mathrm{d}}$ value of the radioligand was somewhat lower than that estimated from the affinity of the nonradiolabeled MRS1898, which may be affected by its hydrophobic nature. The $\operatorname{cLogP}$ for MRS1898 was 2.43, which was considerably higher than the $\operatorname{cLog} \mathrm{P}(1.20)$ for the corresponding 9-riboside, Cl-IB-MECA 2. The frequently used radioligand I-AB-MECA 3 had a cLogP of -0.47 . Thus, further efforts are needed toward the design of a similar radioligand with subnanomolar affinity and subtype selectivity, but with lower nonspecific binding, for applications such as autoradiography. Nevertheless, our study demonstrated that $\left[{ }^{125} \mathrm{I}\right] \mathrm{MRS} 1898$ should be useful under certain conditions for the study of the $\mathrm{rA}_{3} \mathrm{AR}$. Its $\mathrm{A}_{3} \mathrm{AR}$ selectivity is clearly superior to the widely used $\left[{ }^{125} \mathrm{I}\right] \mathrm{I}-\mathrm{AB}-\mathrm{MECA}$.

In summary, a novel selective $\mathrm{A}_{3} \mathrm{AR}$ radioligand, $\left[{ }^{125} \mathrm{I}\right]$ MRS1898, was synthesized and pharmacologically characterized in binding to cell membrane receptors. The advantages of this radioligand compared with other previously used radioligands are its facile synthesis and radiochemical stability and its high selectivity and high affinity for the $\mathrm{rA}_{3} \mathrm{AR}$, which should be applicable for the study of $\mathrm{A}_{3} \mathrm{AR}$ in native tissues with mixed AR subtypes. The binding of $\left[{ }^{125} \mathrm{I}\right]$ MRS1898 to the $A_{3} A R$ in other species and the feasibility of its use in quantification of the $A_{3} A R$ from various tissues may now be studied.

Acknowledgments This research was supported by the Intramural Research Programs of the NIH, National Institute of Diabetes and Digestive and Kidney Diseases, and the Molecular Libraries and Imaging component of the NIH Roadmap for Medical Research

\section{References}

1. Fredholm BB, IJzerman AP, Jacobson KA, Klotz KN, Linden J (2001) International Union of Pharmacology. XXV. Nomenclature and classification of adenosine receptors. Pharmacol Rev 53:527552

2. Baraldi PG, Cacciari B, Romagnoli R, Merighi S, Varani K, Borea PA, Spalluto G (2000) Adenosine Receptor Ligands: History and Perspectives. Med Res Rev 20:103-128

3. Jacobson KA, Gao ZG (2006) Adenosine receptors as therapeutic targets. Nat Rev Drug Discov 5:247-264

4. Müller CE (2000) Adenosine receptor ligands-recent developments part I. Agonists. Curr Med Chem 7:1269-1288

5. Gao ZG, Jacobson KA (2007) Emerging adenosine receptor agonists. Expert Opin Emerg Drugs 12:479-492

6. Madi L, Ochaion A, Rath-Wolfson L, Bar-Yehuda S, Erlanger A, Ohana G, Harish A, Merimski O, Barer F, Fishman P (2004) The $\mathrm{A}_{3}$ adenosine receptor is highly expressed in tumor versus normal cells: potential target for tumor growth inhibition. Clin Cancer Res 10:4472-4479

7. Gessi S, Merighi S, Varani K, Cattabriga E, Benini A, Mirandola P, Leung E, Mac Lennan S, Feo C, Baraldi S, Borea PA (2007) Adenosine receptors in colon carcinoma tissues and colon tumoral cell lines: focus on the $\mathrm{A}_{3}$ adenosine subtype. J Cell Physiol 211: 826-836

8. Olah ME, Gallo-Rodriguez C, Jacobson KA, Stiles GL (1994) ${ }^{125}$ I-4-aminobenzyl-5' $\phi$-N-methylcarboxamidoadenosine, a high affinity radioligand for the rat $\mathrm{A}_{3}$ adenosine receptor. Mol Pharmacol 45:978-982

9. Baraldi PG, Tabrizi MA, Romagnoli R, Fruttarolo F, Merighi S, Varani K, Gessi S, Borea PA (2005) Pyrazolo[4,3-e]1,2,4-triazolo [1,5-c]pyrimidine ligands, new tools to characterize $\mathrm{A}_{3}$ adenosine receptors in human tumor cell lines. Curr Med Chem 12:13191329

10. Müller CE (2003) Medicinal chemistry of adenosine $A_{3}$ receptor ligands. Curr Top Med Chem 3:445-462

11. Klotz KN, Hessling J, Hegler J, Owman C, Kull B, Fredholm BB, Lohse MJ (1998) Comparative pharmacology of human adenosine receptor subtypes - characterization of stably transfected receptors in CHO cells. Naunyn Schmiedebergs Arch Pharmacol 357:1-9

12. Klotz KN, Falgner N, Kachler S, Lambertucci C, Vittori S, Volpini R, Cristalli G (2007) $\left.{ }^{3} \mathrm{H}\right]$ HEMADO-a novel tritiated agonist selective for the human adenosine $\mathrm{A}_{3}$ receptor. Eur $\mathrm{J}$ Pharmacol 556:14-18

13. Madi L, Cohen S, Ochayin A, Bar-Yehuda S, Barer F, Fishman P (2007) Overexpression of $A_{3}$ adenosine receptor in peripheral blood mononuclear cells in rheumatoid arthritis: involvement of nuclear factor-kappaB in mediating receptor level. J Rheumatol 34:20-26

14. Gao ZG, Blaustein J, Gross AS, Melman N, Jacobson KA (2003) $N^{6}$-Substituted adenosine derivatives: Selectivity, efficacy, and species differences at $\mathrm{A}_{3}$ adenosine receptors. Biochem Pharmacol 65:1675-1684

15. Volpini R, Dal Ben D, Lambertucci C, Taffi S, Vittori S, Klotz KN, Cristalli G (2007) $N^{6}$-Methoxy-2-alkynyladenosine derivatives as highly potent and selective ligands at the human $\mathrm{A}_{3}$ adenosine receptor. J Med Chem 50:1222-1230

16. Jacobson KA, Ji X-d, Li AH, Melman N, Siddiqui MA, Shin KJ, Marquez VE, Ravi RG (2000) Methanocarba analogues of purine nucleosides as potent and selective adenosine receptor agonists. J Med Chem 43:2196-2203

17. Lee K, Ravi RG, Ji X-d, Marquez VE, Jacobson KA (2001) Ringconstrained $(\mathrm{N})$ methanocarba-nucleosides as adenosine receptor agonists: Independent $5 \phi$-uronamide and $2 \phi$-deoxy modifications. Bioorg Med Chem Lett 11:1333-1337

18. Tchilibon S, Joshi BV, Kim SK, Duong HT, Gao ZG, Jacobson KA (2005) (N)-Methanocarba 2,N6-disubstituted adenine nucleosides as highly potent and selective $\mathrm{A}_{3}$ adenosine receptor agonists. J Med Chem 48:1745-1758

19. Vaidyanathan G, Zalutsky MR (2006) Preparation of N-succinimidyl 3 -[*I]iodobenzoate: an agent for the indirect radioiodination of proteins. Nat Protocols 1:707-713

20. Cheng Y-C, Prusoff WH (1973) Relationship between the inhibition constant $(\mathrm{Ki})$ and the concentration of inhibitor which causes $50 \%$ inhibition (I50) of an enzymatic reaction. Biochem Pharmacol 22:3099-3108

21. Zhou QY, Li C, Olah ME, Johnson RA, Stiles GL, Civelli O (1992) Molecular cloning and characterization of an adenosine receptor: the $\mathrm{A}_{3}$ adenosine receptor. Proc Natl Acad Sci USA 89: $7432-7436$ 